\begin{tabular}{l|l} 
університет фізичного виховання і спорту України \\
(Київ, Україн)
\end{tabular}

УДК 369.014.3

doi: 10.15330/fcult.34.39-45 Анна Гакман

\title{
ВПЛИВ УНІВЕРСИТЕТІВ ТРЕТЬОГО ВІКУ НА ПСИХОФІЗИЧНУ АКТИВНІСТЬ ОСІБ СТАРШОГО ПОКОЛІННЯ
}

Мета. Визначити можливості впливу інтеграції університетів третього віку в освітнє середовище на психофізичний стан осіб старшого покоління Методи. Під час дослідження використовували аналіз наукових джерел, методи теоретичної інтерпретаџії (аналіз, синтез, індукиія, дедукція, узагальнення), сочіологічні методи (анкетування). Дослідження проводилося на базі "Університету третього віку” на базі Чернівецького комунального територіального центру соціального обслуговування "Турбота" та Чернівецькому університеті третього віку імені А. Кольпінга. У соиіологічному опитуванні прийняло участь 103 особи. Результати. Означено дві моделі діяльності УТВ, які функціонують в Україні, виокремлено основні функиї, які виконує освіта в житті старшого покоління, виділено засоби, які сприяють процесу розвитку старших людей у стінах УТВ, виявлено сочіальні функиії УТВ. Під час соціологічного дослідження виявлені провідні мотиви відвідування університету людьми похилого віку. Розкрито основні форми інтелектуальної активізації людей похилого віку в УТВ. Висновок. Відвідування університетів третього віку позитивно позначається на фізичному й емочійному стані людей старшої вікової групи, проте для отримання таких результатів потрібно від 5 до 10 років навчання. Прогнози вказують на те, щуо популярність навчання в изих університетах буде зростати, оскільки постійно підвищується освітній рівень осіб старшої вікової групи. Це актуалізує проблему подальшої інтеграції їх в освітній простір, особливо в аспекті рекреаційно-оздоровчої діяльності.

Ключові слова: університет третього віку, похилий вік, психофізичний стан. 
The article discusses the problem of having an orderly relationship between old people within the walls of a university of third age. The purpose of the study is to determine, on the basis of theoretical and methodological analysis, the integration of the third-generation university for the elderly. Research methods and organization: analysis of literary sources, methods of theoretical interpretation (analysis, synthesis, induction, deduction, generalization), sociological methods of research (questioning). The study was conducted on the basis of "Third Age University" on the basis of the Chernivtsi Municipal Territorial Center for Social Services "Turbot" and the A. Kolping Third Chernivtsi University. 103 people took part in the poll. Results. Two models of UTA activity that function in Ukraine are identified, the main functions performed by education in the life of the older generation are identified, the means that contribute to the process of development of older people within the walls of UTA are identified, social functions of UTA are identified. The sociological research revealed the leading motives for attending university for the elderly. The basic forms of intellectual activation of the elderly in UTA are revealed. Conclusion. Thus, during their existence, UTA have become an important component of the system of continuing education, have become a powerful factor in the education of older people, their comprehensive activation and gerontological prevention. Hearing students form a specific group, characterized by a high level of formal education and social activity, as well as sufficient financial support. Attending UTA has a positive effect on the development of the elderly, their worldview and emotional state, but to obtain such results requires 5 to 10 years of study. Projections indicate that the popularity of teaching in the UTA will increase as the educational level of older people is steadily increasing. This actualizes the problem of further improvement of the UTA activities.

Keywords: university of the third age, old age, psychophysical state.

Постановка проблеми й аналіз результатів останніх досліджень. Процес старіння населення, який активно відбувається в усьому світі, створює принципово нову ситуацію в багатьох областях суспільного буття (соціальної, економічної, політичної), вимагає комплексної оцінки наслідків, розробки конкретних заходів і принципово нових, інноваційних підходів для рішення багатьох питань, пов'язаних з максимально продуктивним використанням потенціалу численної демографічної групи - осіб похилого віку. Вже зараз вчені звертають серйозну увагу на важливість процесу підготовки до старості, профілактики передчасного старіння, максимально можливого продовження повноцінної діяльності, створення умов для підтримки різних видів активності людей похилого віку.

Інтенсивне та швидке старіння українського населення протягом минулого століття має глибокі наслідки для нашого суспільства. Виходячи з еволюційних тенденцій народжуваності, смертності та міграційних рухів, схильність до “перевернутої піраміди” епохи, здається, є найбільш акредитованою справді з прогресивним дисбалансом на користь старшого віку.

Ми могли б визначити як позитивні, так і негативні наслідки цього явища. Поперше, старіння населення $є$ успішним, оскільки це свідчить про значне поліпшення умов життя та охорони здоров'я у нашій державі. По-друге, це являє собою інновацію нових потреб, які суспільство ще не в змозі виконати, як, наприклад, орієнтація на здорове старіння населення через залучення до рухової активності осіб похилого віку.

Зважаючи на демографічний склад населення, необхідно усвідомлювати цю зміну, щоб максимально використати всі можливості та протидіяти негативним наслідкам старіння. Тому необхідно розробляти концепції до залучення старших людей до рухової активності, які будуть уповільнювати темпи старіння, підтримувати рівень здоров'я людей похилого віку та сприяти їх кращій соціалізації у новому статусі “пенсіонер”.

Серед сучасних досліджень закордонних та вітчизняних науковців зверталася увага на університети “третього віку” як складової безперервної освіти (Федоренко С. А., 2012; Скорик Т.В., 2014 та ін.), досліджувалось поняття “Активного старіння” в контексті проблеми освіти людей похилого віку (Сагун І. Г., 2010; Робак В.С., 2011; Гакман А.В., 2018; Дудіцька С.П., 2019 та ін.), соціально-педагогічне середовище університету третього віку як чинник формування життєдіяльності людей похилого віку (Житинська М. О.,2016; Попик Ю.В., 2016). Проте, серед означених робіт нами не 
виявлено досліджень, які б акцентувало увагу на інтеграцію університету третього віку для осіб старшого покоління, що й зумовлює актуальність дослідження.

Мета дослідження - на основі теоретико-методологічного аналізу визначити можливості впливу інтеграції університетів третього віку в освітнє середовище на психофізичний стан осіб старшого покоління.

Методи й організація дослідження. Для досягнення поставленої мети застосовувалися комплекс взаємопов'язаних та взаємодоповнюючих методів дослідження: аналіз літературних джерел, методи теоретичної інтерпретації (аналіз, синтез, індукція, дедукція, узагальнення), соціологічні методи дослідження (анкетування). Дослідження проводилося на базі "Університету третього віку" на базі Чернівецького комунального територіального центру соціального обслуговування "Турбота" та Чернівецькому університеті третього віку імені А. Кольпінга. У соціологічному опитуванні прийняло участь 103 особи.

Результати дослідження і дискусія. Однією з ефективних форм вирішення цих проблем стали університети третього віку (УТВ). Як відомо, рух УТВ виник у Франції, де в 1972 р в Тулузі професор Pierre Vellas заснував перший такий заклад. Ідея виявилася настільки плідною, що досить швидко УТВ почали виникати і в інших країнах: спочатку в Бельгії, Канаді, Швейцарії, а потім в Іспанії, Італії, Швеції, Норвегії, Англії, Німеччини [4, 6, 8, 10 та ін.].

Поступово сформувалися дві моделі діяльності УТВ - французька і британська. Французька модель характеризується високим рівнем дидактичної та науководослідницької діяльності. Ступінь інтеграції з вузом може бути різноманітною: від повної інтеграції до повної незалежності від нього. Лекції в УТВ проводять викладачі академічних університетів. Така модель УТВ була реалізована в Бельгії, Іспанії, Італії, Швеції та Україні [7, 9].

На відміну від французької британська модель, розроблена Paul Laslett, базується на взаємодопомозі самих слухачів, які $\epsilon$ одночасно і викладачами, і учнями [11]. Головними рисами британської моделі є:

- відсутність допомоги з боку вузу;

- взаємодопомога як головний метод навчання;

- відсутність поділу на студентів і викладачів;

- акцент на спільне, групове освіту;

- організація занять силами слухачів, при використанні їх знань і досвіду [5, с. 5].

Саме ця модель користується найбільшою популярністю в більшості країн світу, оскільки дозволяє економити кошти на викладачах.

Фактично сьогодні в Україні діють два типи УТВ. Перший - це створені на основі французької моделі установи, які тісно пов'язані з вузами і забезпечують академічний рівень освіти. Другий тип - це структури, діяльність яких спрямована на активізацію старих людей в широкому розумінні цього слова. Вони не так тісно пов'язані з вузами, хоча також забезпечують високий рівень занять [12].

На сьогоднішній день УТВ $є$ важливою складовою частиною системи безперервної освіти в Європі, адже документи ЄС гарантують жителям право на освіту незалежно від віку. Головною метою діяльності УТВ $є$ активізація слухачів в широкому розумінні, тобто інтелектуальна, соціальна і фізична.

3 цією метою УТВ підтримують тісні контакти з різними установами та організаціями, які працюють в локальному середовищі. Найчастіше це освітні та культурні установи, організації соціальної допомоги [11].

Виділяють дві головні функції УТВ - освітню та рекреаційно-інтеграційну [2]. Для реалізації рекреаційно-інтеграційної функції використовують різноманітні форми 
діяльності. Умовно їх можна розділити на такі групи: культурно-артистична, рекреаційно-оздоровча і розважальна. Слід зазначити, що освітня діяльність і на сьогоднішній залишається провідною для більшості УТВ.

Це пов'язано з важливістю і різноманітністю функцій, які виконує освіта в житті старшого покоління, зокрема:

- інструментальна - засіб вирішення проблем, пов'язаних з періодом старості;

- екзистенційна - освіта як шлях до осмислення феномена життя, який дозволяє прийняти життя, знайти в ній сенс;

- соціальна та культурно-цивілізаційна - освіта як стиль життя, активний спосіб проведення часу в період старості, результатом чого є зміцнення соціальних позицій особистості;

- ауксологічна - освіта як одна 3 форм профілактики атрофії, фактор, який стимулює зміни в особистості старших людей;

- аксиологічно-телеологічна - освіта направляє особу до повноти духовного сприйняття, зрілості;

- феліцитологічна - освіта як активність, вид діяльності, що приносить радість [3].

Деякі українські вчені вважають, що діяльність УТВ сприяє процесу розвитку старших людей. При цьому використовуються різні засоби, зокрема:

- освітні засоби, пов'язані з навчанням старших людей (слово, приклад, переконання, виховна ситуація);

- діяльність з самоосвіти і самовихованню;

- ініціативи, які мають на меті модернізації середовища проживання старших людей з метою створення умов для стимулювання їх розвитку (соціальна і культурна інфраструктура) [1].

Навчання в УТВ має важливе значення для людей похилого віку. Відомо, що більш високий освітній рівень дозволяє їм краще пристосовуватися до технологічних i соціальних змін, які неминуче супроводжують розвиток цивілізації, полегшує взаємодію між поколіннями, формує у них певні потреби, наприклад, власного розвитку, що в кінцевому рахунку призводить до соціальної, фізичної та інтелектуальної активізації [5].

Крім освітньої УТВ виконують і інші важливі соціальні функції:

а) функцію приєднання; вона реалізується шляхом встановлення контактів 3 іншими людьми, у яких схожі інтереси, появи друзів, отримання позитивного емоційного досвіду;

б) інтеграційну функцію - об'єднання людей з аналогічними проблемами (наприклад, соціальними, економічними) для появи у них почуття безпеки, спільноти;

в) експресивну функцію, яка проявляється в появі потреби в активності, творчості, хобі;

г) профілактичну функцію: звільняє старших людей від соціальної ізоляції, самотності, маргіналізації, моногонії, передчасного старіння;

д) функцію накопичення і трансляції досвіду: організатори і викладачі УТВ навчаються самостійно (часто методом проб і помилок), вдосконалюють свою діяльність, впроваджують нові форми і методи роботи, обмінюються досвідом [9].

У сучасній Європі, в тому числі і в Україні, простежується стійка тенденція до зростання популярності УТВ, збільшення їх кількості і числа слухачів. Причини цього вбачають у збільшенні чисельності людей похилого віку, зростанні тривалості життя, поліпшення стану здоров'я старшої вікової групи, зростанні рівня формальної освіти серед цієї категорії населення [4]. Формальні вимоги до учасників відсутні. Мабуть, єдине - вік (не менше 40 років). Навчання добровільна, ніякого примусу. За бажанням учасників заняття проводяться, як правило, 1-2 рази на тиждень тривалістю 2-4 години. 
Більшість слухачів УТВ - це інтелігенція, представники розумової праці (інженери, педагоги, держслужбовці); рідше зустрічаються лікарі, юристи і рідше - різноробочі чи домогосподарки. Освітні програми в українських УТВ відвідують переважно самотні жінки (87\% від числа всіх учасників). Аналогічна ситуація спостерігається як в Європі, так і в усьому світі. Очевидно, це обумовлено кількісним домінуванням жінок в цій віковій групі, бажанням компенсувати самотність, низьким рівнем їх професійної активності (в порівнянні з чоловіками), переважно гуманітарними спеціальностями жінок, що більш відповідає тематиці занять в УТВ [10].

У нашому соціологічному дослідженні прийняли участь 103 особи, які відвідують "Університет третього віку" на базі Чернівецького комунального територіального центру соціального обслуговування “Турбота" та Чернівецький університет третього віку імені А. Кольпінга. Серед респондентів переважали люди похилого віку - 70,9\%, $20,4 \%$ слухачів - у віці до 59 років, решта (8,7\% - довгожителі). Слухачі українських УТВ - це люди із високим рівнем формальної освіти. Більше половини з них мають середню освіту, а 47,6\% - вищу. Оскільки середній освітній рівень популяції людей похилого віку в Україні істотно нижче, це свідчить про те, що в УТВ приходять слухачі $з$ високим рівнем освіти.

Результати анкетування слухачів УТВ показали, що провідним мотивом відвідування університету є потреба в розширенні знань $(24,6 \%)$ і підтримки розумової працездатності $(24,2 \%)$. Часто також називають бажання налагодити контакти 3 ровесниками (20,8\%). Тільки 15\% вказали на самотність як причину відвідин УТВ.

В УТВ використовуються різні форми інтелектуальної активізації слухачів. Все УТВ пропонують лекції, більшість - семінари, заняття в групах за інтересами. Найбільшою популярністю користуються лекції та екскурсії. 20\% опитаних відзначили, що вважають за краще групи за інтересами і лекції з вивчення іноземних мов.

Ці форми вибирають переважно жінки, тоді як чоловіки більше схильні до дискусій. В цілому 78\% опитаних підтвердили, що УТВ позитивно впливають на розвиток їх інтересів.

Крім освітньої, важливими складовими діяльності УТВ є соціальна та фізична активізація слухачів. Рухова активність найчастіше реалізується на заняттях гімнастики, оздоровчого бігу та ходьби, плаванням.

У відповідях на питання анкети слухачі відзначили, що завдяки УТВ покращилися їх відносини з оточенням, відвідування університету також позитивно вплинуло на їх поведінку. Серед позитивних моментів відзначають отримання задоволення від життя $(34,1 \%)$, приплив життєвої енергії $(32,7 \%)$, вони рідше відчувають почуття смутку $(17,4 \%)$, менше думають про здоров'я $(15,8 \%)$. Однак поява таких позитивних почуттів відбувається не відразу. Найчастіше такі зміни декларували респонденти, які відвідували УТВ від 5 до 10 років.

Необхідно підкреслити, що УТВ є тим місцем, де люди похилого віку, використовуючи власні можливості, протидіють передчасному старінню. В результаті вони можуть довше жити незалежно і самостійно. Вони відсувають час, коли за ними необхідно буде доглядати, опікати їх, а це має важливе значення для політики охорони здоров'я та соціальної допомоги.

\section{Висновок.}

Таким чином, за час свого існування УТВ стали важливою складовою системи безперервної освіти, перетворилися в потужний фактор освіти людей похилого віку, їх психофізичної активізації та геронтологічної профілактики. Слухачі УТВ утворюють специфічну групу, для якої характерні високий рівень формальної освіти і громадської активності. Відвідування УТВ позитивно позначається на фізичному й емоційному 
стані людей похилого віку, проте для отримання таких результатів потрібно від 5 до 10 років навчання. Прогнози вказують на те, що популярність навчання в УТВ буде зростати, оскільки постійно підвищується освітній рівень осіб старшої вікової групи. Це актуалізує проблему подальшого вдосконалення діяльності УТВ, особливо в аспекті рекреаційно-оздоровчої діяльності.

1. Гакман АВ. Роль рухової активності та процесів старіння для осіб похилого віку. Young. 2018: 55 (3): 34-37.

2. Гакман А. Структура захворюваності людей похилого віку у демографічному контексті. Слобожанський науково-спортивний вісник. 2019;5 (73): 88-91.

3. Дудіцька С, Гакман А, Випасняк I. О Аналіз структури вільного часу жінок похилого віку. Фізична культура, спорт та здоров'я нації: збірник наукових праць. Вип. 7(26). Вінниця: ТОВ “Планер”, 2019: $50-56$.

4. Дудіцька СП. Вітчизняний та зарубіжний досвід використання засобів оздоровчо-рекреаційної рухової активності у людей похилого віку. Науковий часопис Національного педагогічного університету імені М. П. Драгоманова. Серія 15 : Науково-педагогічні проблеми фізичної культури (фізична культура і спорт): зб. наук. праць. Київ: Вид-во НПУ імені М. П. Драгоманова, 2019;(111): С. 56-61.

5. Житинська МО. Соціально-педагогічне середовище університету третього віку як чинник формування життєдіяльності людей похилого віку. Соціальна робота в Україні : теорія і практика : науково-методичний журнал. Київ : Вид-во НПУ імені М. П. Драгоманова, 2016;1-2: 131-139.

6. Попик ЮВ. Освіта людей третього віку як засіб соціальної адаптації та інтеграції. Педагогічний альманах. 2016;32:229-234.

7. Про внедрение социально-педагогической услуги "Университет третьего возраста": приказ Министерства социальной политики Украины от 25 августа 2011 года № 326.

8. Робак ВС. Проблематика старіння в інтердисциплінарному контексті : понятійно-термінологічний апарат. Вісн. Черкаського ун-ту. Серія “Пед. науки". 2011; 20(III): 90-98.

9. Сагун ІГ. Поняття “Активного старіння" в контексті проблеми освіти людей похилого віку в Європейській спільноті. Вісник Хмельницького національного університету. 2010: 45-49.

10. Скорик ТВ. "Університет третього віку": концептуальні положення та досвід реалізації. Вісник Чернігівського національного педагогічного університету імені Т. Г. Шевченка. Текст. Чернігів: ЧНПУ (Серія: Педагогічні науки). 2012; 2(104): 94-98.

11. Скорик ТВ, Шевченко IC. Університет третього віку як модель соціальної інтеграції осіб літнього віку в сучасне суспільство. Вісник Львівського університету. Серія соціологічна. 2014; 8: 60-68.

12. Федоренко СА. Університети “третього віку” як складова безперервної освіти; зарубіжний досвід. Педагогічний процес: Теорія і практика. 2014; 1: 133-138.

13. Andrieieva O, Hakman A, Kashuba V, Vasylenko M, Patsaliuk K, Koshura A. et al. Effects of physical activity on aging processes in elderly persons. Journal of Physical Education \& Sport. (Supplement issue 4). 2019: 1308-1314.

\section{References}

1. Hakman AV. Rol rukhovoi aktyvnosti ta protsesiv starinnia dlia osib pokhyloho viku. Young. 2018. T. 55. №. 3.3: 34-37.

2. Hakman A. Struktura zakhvoriuvanosti liudei pokhyloho viku u demohrafichnomu konteksti. Slobozhanskyi naukovo-sportyvnyi visnyk. 2019. №. 5 (73): 88-91.

3. Duditska S, Hakman A, Vypasniak I. O Analiz struktury vilnoho chasu zhinok pokhyloho viku. Fizychna kultura, sport ta zdorovia natsii: zbirnyk naukovykh prats. Vyp. 7(26). Vinnytsia: TOV "Planer", 2019: 50-56.

4. Duditska SP. Vitchyznianyi ta zarubizhnyi dosvid vykorystannia zasobiv ozdorovcho-rekreatsiinoi rukhovoi aktyvnosti u liudei pokhyloho viku. Naukovyi chasopys Natsionalnoho pedahohichnoho universytetu imeni M. P. Drahomanova. Seriia 15 : Naukovo-pedahohichni problemy fizychnoi kultury (fizychna kultura i sport) : zb. nauk. prats. Kyiv : Vyd-vo NPU imeni M. P. Drahomanova, 2019. Vyp. 3 (111): 56-61.

5. Zhytynska M O. Sotsialno-pedahohichne seredovyshche universytetu tretoho viku yak chynnyk formuvannia zhyttiediialnosti liudei pokhyloho viku. Sotsialna robota v Ukraini : teoriia i praktyka : naukovo-metodychnyi zhurnal. Kyiv : Vyd-vo NPU imeni M. P. Drahomanova, 2016. № 1-2: 131-139.

6. Popyk Yu V. Osvita liudei tretoho viku yak zasib sotsialnoi adaptatsii ta intehratsii. Pedahohichnyi almanakh. 2016. №. 32: 229-234.

7. Pro vnedrenye sotsyalno-pedahohycheskoi usluhy "Unyversytet treteho vozrasta" : prykaz Mynysterstva sotsyalnoi polytyky Ukraynd ot 25 avhusta 2011 hoda № 326.

8. Robak VIe. Problematyka starinnia $\mathrm{v}$ interdystsyplinarnomu konteksti : poniatiino-terminolohichnyi aparat. Visn. Cherkaskoho un-tu. Seriia "Ped. nauky". 2011. Vyp. 203. Ch. III: 90-98. 
9. Sahun IH. Poniattia “Aktyvnoho starinnia” v konteksti problemy osvity liudei pokhyloho viku v Yevropeiskii spilnoti. Visnyk Khmelnytskoho natsionalnoho universytetu. 2010: 45-49.

10. Skoryk TV. "Universytet tretoho viku": kontseptualni polozhennia ta dosvid realizatsii. Visnyk Chernihivskoho natsionalnoho pedahohichnoho universytetu imeni T. H. Shevchenka. Tekst. T. 2. Vyp. 104 Chernihiv: ChNPU, 2012. (Seriia: Pedahohichni nauky): 94--98.

11. Skoryk TV, Shevchenko IS. Universytet tretoho viku yak model sotsialnoi intehratsii osib litnoho viku v suchasne suspilstvo. Visnyk Lvivskoho universytetu. Seriia sotsiolohichna. 2014. Vyp. 8: S. 60-68

12. Fedorenko SA. Universytety "tretoho viku" yak skladova bezperervnoi osvity; zarubizhnyi dosvid. Pedahohichnyi protses : Teoriia i praktyka. 2014. Vyp. 1: 133-138.

13. Andrieieva O, Hakman A, Kashuba V, Vasylenko M, Patsaliuk K, Koshura A. et al. Effects of physical activity on aging processes in elderly persons. Journal of Physical Education \& Sport. 2019 (Supplement issue 4): 1308-1314.

Цитування на цю статтю:

Гакман АВ. Вплив університетів третього віку на психофізичну активність осіб старшого покоління. Вісник Прикарпатського університету. Серія: Фізична культура. 2019 Листоп 27; 34: 39-45

\begin{tabular}{l:l} 
Відомості про автора: & Information about the author: \\
\hdashline Гакман Анна Вікторівна - кандидат наук з фізич- & Hakman Anna Viktorivna - Candidate of Science \\
ного виховання і спорту, доцент кафедри теорії та & (Physical Education and Sport), Associate Professor \\
методики фізичного виховання і спорту, Чернівець- & (Ph. D.), Yuriy Fedkovych Chernivtsi National Uni- \\
кий національний університет імені Юрія Федь- & versity (Chernivtsi, Ukraina) \\
ковича (Чернівці, Україна) &
\end{tabular}

УДК 615.825-053.4+616-017.2:57.018.7:373.2 $\quad$ Віталій Кашуба, Наталія Носова,
doi: 10.15330/fcult.34.45-52 Tетяна Коломієць, Олена Бондар, Богдан Лісовський

\section{АПРОБАЦІЯ КАРТИ СКРИНІНГ-КОНТРОЛЮ БІОГЕОМЕТРИЧНОГО ПРОФІЛЮ ПОСТАВИ ДІТЕЙ ДОШКІЛЬНОГО ВІКУ В ПРОЦЕСІ ФІЗИЧНОЇ РЕАБІЛІТАЦІї}

Мета. Розробити та апробувати карту візуального скринінгу біогеометричного профілю постави дітей 5-6 років у процесі фізичної реабілітації. Методи. У процесі дослідження використано метод аналізу науково-методичної літератури, соиіологічні методи (анкетування, опитування), методи кваліметрії та методи математичної статистики. Основним методом дослідження обрано педагогічний експеримент. Констатувальний етап передбачав отримання інформації про стан біогеометричного профілю постави дітей 5-6 років (n=76) у прочесі фізичної реабілітації. Результати. Науково обтрунтована та апробована карта скринінг-контролю стану біогеометричного профілю постави дітей 5-6 років у прочесі фізичної реабілітачїі, в умовах закладів дошкільної освіти, для своєчасної профілактики та корекиії ї̈ порушень. Розроблена карта дає можливість розділити дітей з функціональними порушеннями постави за такими рівнями стану їх біогеометричного профілю постави:високий, вище за середній, середній та низький. Використання розробленої технології контролю стану біогеометричного профілю постави дітей 5-6 років у процесі фізичної реабілітації дозволило розподілити дітей з різними типами порушення постави за рівнями стану біогеометричного профілю. Отримані результати дослідження являлись підгрунтям для розробки комплексів фізичних вправ окремо для кожного типу постави на різних періодах фізичної реабілітації з урахуванням рівнів стану біогеометричного профілю постави дітей 5-6 років. Висновок. За рівнем стану біогеометричного профілю у 10,53\% обстежених дітей зафіксовано низький рівень стану біогеометричного профілю постави за наявності комбінованих порушень постави у фронтальній і сагітальній площинах, у 19,74\% зареєстровано вище за середній рівень стану біогеометричного профілю постави за наявності такого порушення останньої, як сутула спина.

Ключові слова: контроль, біогеометричний профіль постави, діти старшого дошкільного віку, фізична реабілітаџія.

(C) Кашуба В., Носова Н., Коломієць Т.,

Бондар О., Лісовський Б., 2019 